\title{
The Ethics of Censorship based on Islamic Perspective: The Impact towards Intellectual Freedom
}

\author{
${ }^{1}$ Muharman Lubis and ${ }^{2}$ Anik Hanifatul Azizah \\ ${ }^{1}$ muharmanlubis@telkomuniversity.ac.id, ${ }^{2}$ anikhanifazizah@gmail.com \\ Telkom University
}

\begin{abstract}
In the name of Allah, most Gracious and most Merciful. There are numerous reasons why countries conduct the censorship upon information access through legal regulation, for example the protection of social norm, the restriction of the opposition movement, securing government assets, preserving the individual right of privacy and religious compliance. However, the absolute or even partial authority of controlling the information circulation has a tendency to be misused for the sake of private interest, which can lead to the instability of economy and politics in the long run. There is no doubt that censorship should be carried out in a number of cases like for preventing cyber crime or defamation. Therefore, the important aspects of ethical concern namely positive outcome, respect for the citizen's right, social consensus and God consiousness should be considered respectively in developing the proper strategy to anticipate citizen's resistancies or inability of respected apparatus to maintain the situation. The purpose of this study is to explore the proper mechanism in implementing the censorship strategy to obtain the intended objectives by looking deeply and extensively the guidances based on Islamic perspective in relation to the ethical concern, which consist of moral commandments, accountability of rulers, social values, progressive benefits, equality of treatment and community interest. On the other hand, the clear distinct between the sacred text and sayings with individual roles has openned the discussion upon the limit of intellectual freedom. Thus, the analysis on the impact should be presented to depict the clear picture on the relationship between the activities that should and should not be done in order to prevent worst case scenarios.
\end{abstract}

Keywords: Islamic Perspective, Freedom, Censorship, Ethic.

\section{Introduction}

According to Al Quran [1], specifically Surah Saba 34:28 and Surah Al An'am 6:114, Muslims are responsible for their work on Islam as a way of life, which must arise on earth for the rule of Muslims and non-Muslims until the Day of Resurrection, of course Muslims must follow them as their belief completely and not partially. In Islam, Al Quran is the primary sources and references to govern the society by providing the general concept of regulation, while specific detail are explained by Sunnah based on the behavior of the Prophet such as ethical conditions and practical application mentioned in Shahih Bukhari, book of Food and Meal hadith no. 5377 that instruct to eat the dish what is nearer or Shahih Muslim, book of Gift hadith no. 3949 that mentioned the one who gets back the charity is like a dig who swallows its vomit [2]. In the context of Indonesia, with ministerial regulation No. 19 of 2014, on July 17, 2014, concerning the handling of negatively charged internet sites, the government has 
determined its stance to block internet sites that contain elements of pornography, gambling and illegal activities based on legislation in which the collection of sites blocked ones will be saved in a list called TRUST + Positive. this policy as an attempt to carry out the law as strictly as in article 40 paragraph (2) Law No. 11 of 2008 concerning Information and Electronic Transactions (ITE) which mentions government protection of the public interest in all types of misuse of misuse of Information and Electronic Transactions and also Article 17 of Law No. 44 of 2009 concerning Pornography which gives a portion of the obligations of the Government and Regional Government to prevent the creation, dissemination and use of pornography. Therefore, the censorship policy carried out by the government aims to limit the spread of negative content such as pornography and radicalism that can impact the thinking of the wider community into wrongful direction.

In practice, the government has blocked several internet sites that have received pro or con responses such as 4chan, telegram, tumblr, imgur, BoyAhoy, Grindr, Blued, Giphy, TikTok, Reddit, Vimeo, Bigo Live and many other cases. However, in its implementation throughout the years, there are various opposing views that depict the government has reduced the quality of freedom in term of opinion and expression that has been guaranteed by the constitution of article 28E paragraph (3). Furthermore, the existence of the Siracusa principles which state that restrictions on human rights must not endanger the essence of rights themselves make every clauses of limitations must be interpreted explicitly, clearly and aimed to support the rights. On the other hand, Islamic principle present the concept of mercy for everyone as the guidance in the interaction process with the others, which has not limited to the human only but also the environment as well. Moreover, the increase number of physical attacks on journalists and bloggers who wrote sensitive topics such as the depravity of the government to the anti- religious offense was considered as an effort to narrow the spaces for freedom of expression by linking political and security issues. Moreover, the limitation is also carried out by the government on personal virtual networks (VPN), streaming video and Voice Over IP (VoIP) so that people still have difficulty accessing sites that have been blocked or at certain conditions. On the other hand, the national and local authorities continued to harass and threaten LGBT (lesbian gay, bisexual, and transgender) people and activists, driving the community further underground. Atheism is not accepted and the criminal code contains provisions against blasphemy, penalizing those who distort or misrepresent recognized faiths. It represented by the foreign media as the national and local governments fail to protect religious minorities and exhibit bias in investigations and prosecutions.

According to Freedom House [3], Indonesia is in the "Partly Free" category with a value of 62 from a maximum of 100 with freedom rating 3/7, political right $2 / 7$ and 4/7 civil liberties with some notes such as blocking gay dating application sites, limiting information about Papua, intimidation against anyone who is considered to attack Islam on the internet, until the arrest of violators of the ITE Law. The same thing was expressed by the South East Asia Freedom of Expression Network (SAFENET) [4] which is regarding press freedom in Indonesia, from 2008 to December 2018 there have been 16 legal cases that attempted to criminalize 14 journalists and 7 media with the rubber article contained in article 22 paragraph 3 of the ITE Law junto Article 45 of the ITE Law and articles 310-311 of the Criminal Code. The 2018 Democracy Index data by the Economist Intelligent Unit (EIU) [5] shows Indonesia is ranked 65 out of 167 countries with a total score of 6.39. The indicators used to measure the level of Indonesian democracy include electoral process and pluralism (6.92), functioning of government (7.14), political participation (6.67), political culture (5.63) and the most important civil liberties (5.59) due to the many cases of silencing freedom of speech. Meanwhile according to the Press Freedom Index [6] in 2019, compiled by Reporters without Border (RWB), in 2015 Indonesia 
was ranked 124 out of 180 index countries based on press freedom with a score of 36.77 . This study has aim to discuss the Islamic perspective to evaluate the censorship policy imbued by the government to restrict citizen activities as the procedure to define the boundaries based on the prior intention to align with the principle objective as well the benefit or impact as the consequences as the implication of the implementation. It has attempt to define the scope and constraint of what is mandatory and purpose should be attained.

\section{Rationale Aspects}

The primary objective of Islamic tenets as the way of life can be categorized as preservation of faith (din), life (al-nafs), mind (al-,aql), progeny (al-nasl), honor (al-,,ird) and property (almal) [7]. Meanwhile, the authors has quoted the sayings of Ibn Qayyim [8] to explain the fundamental principle of Islamic tenets, which are built upon guarding the benefit of people in the world affairs for the sake of hear after with emphasizing justice, mercy, wisdom and interest of the human. Thus, the rational aspects of discussion should align the primary objective of the Islamic tenets, in which faith often looked based on the moral commandments, while life is usually governed by the rulers, then mind is supposed to contribute to the social values, next the progeny as the essence of the benefits that want to achieved, honor lead to the equality of treatment of humankind in the society and lastly the property become the standard of interest in the community.

\subsection{Moral Commandments}

Apart from moral contributions to the growth of science and technology, some areas lack moral control, thus allowing serious challenges and technological risks for the whole world. For truly progressive benefits, science and technology require ethical constraints, especially because the catastrophic consequences of scientific efforts cannot be considered morally neutral. Consequently, this review of Islamic ethics must stimulate new developments in science and technology in connection with Islamic ethics which are applied as evidence to protect humans from destruction due to a decline in morality [8]. The Qur'an gives a clear but sometimes stiff warning to lead a godly life and offers guidance to submit to God and obey orders as an important requirement for faithful believers. The Qur'an, the traditions of the Prophet, or the Sunnah determine the daily values of Muslims. Both the Qur'an and the Sunnah are the main sources that provide principles and guidelines for the life of godly Islam, and believers should be good for all who embrace Islam. However, the definition of moral will can be defined by certain attributes such as free will, kindness, responsibility, balance and unity [9]. Occasionally, it is difficult to understand ethics, values and ethics because misunderstandings and misunderstandings around them prevent access to correct explanations. Therefore it is better to define morals based on the purpose of moral work as an effort to develop a feeling of being together with others and to make someone committed to their personal responsibilities and actions [10].

\subsection{Accountability of Rulers}

Nowadays, the state of most Muslim countries have tendencies to be governed by the dictator rulers wherein the separation of power between the executive, legislative and judicial branches should be established but not with the collective ruling mechanism [11]. Author continued that every human has numerous weaknesses and potentiality of the personality traits, 
it is necessary that the rulers should have the attribute of consiousness of Allah ta'ala with intellectual and emotional strength based on expertise, in which council of Ummah and political parties become the counterbalance to the system with the purpose of consultation and accountability of the rulers. The application of the principle of transparency will open up the required information about the policy setting for all stakeholders, especially the citizens. Through an open government model, people are given the opportunity to study and analyze which policies should be taken based on specific issues so that the community can make observations and provide feedback or recommendation to respective government through available channels [12]. The Islamic ethics, therefore, emphasizes the importance of personal virtue, also focuses on intention rather than outcome, which respects the Qur'an's religious orders and attaches great importance to studying the costs and benefits of ethical decisions for the community rather than a narrow group of stakeholders [9]. However, citizens should obey the rulers patiently although they do a cruel act as long as it does not force to commit actsof disbelief to Alla ta'ala as mentioned in Shahih Muslim, Book on Government, hadith no. 1847 and Shahih Bukhari, Book of Accepting Information given by a Truthful Person, hadith no. 7257, and Book of Judgment, hadith no. 7144 [2].

\subsection{Social Values}

The Islamic ethics can be defined based on its relationship to the individuals such as mentioned in Surah Al A'raf 7:31 about the instruction to eat and drink but avoid the excessive wasting, then to the family like in Surah An-Nisa 4:19 regarding the threatment to wife and Surah Al-Ahqaf 46:15 that discuss on children obligation to take care their parents, lastly to the society, such as Surah An-Nur 24:27 that provides the guidance on the etiquette to enter somebody houses. Therefore, it is believed by Muslim that everyone are born with moral nature that respond to its faith and practice in achieving good characted and contribute to the social value. In its nature, the life has purpose to become slave of Allah ta'ala by discovering the sign of Allah in this world through discovering and investigating to contribute within society [13]]. Those who practice the Islamic faith as true believers try to obey God's laws, where God's honor requires them to work for the welfare of society, their communities, their families, and their own development [9]. One of the most unavoidable and important elements of society is a sense of togetherness as a sense of belonging together in the same group as the desired goal. To maintain this feeling, certain groups need a certain code of ethics and a sense of moral values judged between right and wrong in actions where religion becomes a critical condition for the formulation of other forms of social control [14]. the one who truly believes and practices the tauhid (Oneness of Allah) in his life, then he will be separated from all the bondage of selfservitude to the creature who has no ability to benefit or harm himself, to go to self-surrender to Allah Ta'ala, who has all good, and He is the only creator, ruler and regulator of this universe.

\subsection{Progressive Benefits}

Humanitarian cooperation in an ideal society requires religion, education, economics, political life and law, which Muslims community in various countries, even as minorities, benefit from these social values if they maintain their Islamic identity as the best environmental measure [15]. Moreover, it should be noted that Islamic ethics are highly dependent on Quran and Sunnah as the religious requirements to produce the progressive benefit through regulating certain required aspect by recognizing the importance of avoiding risks and improving the acquisition of qualities for society as a whole [9]. Research indicated that certain Muslim practice their routines by utilizing the proper channel to improve their self-quality such as through download the application to support the process of performing Ibadah (worshipping) or 
acting as the reminder to notify certain event occur during the day and night. Meanwhile, the tools use are quite important to obtain progressive benefits to contribute to the society by playing required role, at least by delivering or spreading one verse from Al Quran with the interpreted context based on proper mechanism [16]. On the other hand, the sample of the above research presented the Internet usage, consist of mild, moderate and severe addiction with $48.5 \%, 44.7 \%$ and $1 \%$ respectively while the rest is the prevelance of normal user, which indicated $80 \%$ acknowledge the progressive benefit regarding the Islamic knowledge and $20 \%$ disagrees with its positive usages. These kind of result could be understood that majority of population have tendency to justifying a thing under the pretext instead of being based on the initial purpose of using something so as not to waste time and opportunities. Therefore, limiting population access to certain sites that contain information that has the potential to threaten the current government, prohibited content can be beneficial to the regime in providing relatively harmless expressions of hate and making the authorities informed several critical thinking offered by the citizens.

\subsection{Equality of Treatment}

According to Islam, what is right and what is wrong cannot be left to certain people because humans have inherent weaknesses that they tend to act in ways that they deem appropriate, regardless of whether this action is not needed or rejected by citizens. Thus, Islamic ethics has the purpose of clarifying the correct activities of the wrong activities to prevent unethical problems from arising [17]. In the everyday life interaction within society that engages the differences in term of gender, racial, social, political and of course religion there are manners values and legal norms that differentiate the roles between both parties, so the equality should not be looked as the similar number of rights and obligations [18]. Basically, as stated in Surah Adh-Dhariyat 51:56, men and women are equally as slaves of Allah ta'ala that have same purpose of submission, then according to Surah An'am 6:165, men and women have same opportunities in the face of earth to make the best use of time in this life as Allah put authority upon them. Meanwhile, based on Surah Al A'raf 7:172 mentioned that men and women receive same primordial covenant in term of individual responsibility and independence and in Surah An Nisa 4:124 show that there is no distinction between men and women to achieve the successes in the world as well hereafter. Unfortunately, there is also view argueing that Islam does not condemn non-heterosexual sexual intimacy as it is embraced as part of a divine plan of true meaning of peace and justice, accomodate the individual's sexual orientation as an intrinsic part of their biological and psychological makeup [19]. However, the equality should be presented in term of treatment, not go beyond that such as claiming that physical and emotional differences are similar to justify the equality of right and obligation.

\subsection{Community Interest}

The relationship between religion and religion in the definition of Muslims takes a distinctive form in changing the concepts and practices of society, namely race and cultural heritage of exclusion in the contemporary definition of Islam [20]. Community leaders and mosques should be invited to meet the needs of a new generation of Muslims in the context of intergenerational instability and conformity with ethnic values [21]. In fact, majority Muslims do not believe in democracy or any other ideals or ideology concept, such as freedom of speech, human rights, gender equality and so on, unless they influences to their personal interests significantly [22]. However, Islam has prohibited specific interest (riba) based on earnings based on Surah Baqarah 2:275 such as simple interest, compund interest, periodic interest, commercial interest, money interest, interest al-nasiah, interest al-fadl and so on, although it occupies a central position in modern economic life and has been regarded as the life blood of the existing 
financial institutions [23]. Thus, the community interest in the property should be earned from legal path according to guidance of Quran and Sunnah, although aspect of agreement and benefit has been taken place within the transaction. In fact, the interest based society and economy are abusive, which give negative impact on the morality as well such as inflation that increase nominal value more than instrinsic value of money, people earn money without any effort, lose their motivation to work through labor, run business with self-owned capital if do not have the wide scope to take loan from interest based bank, oligarchy power that control the flow of money to control political and cultural requrement and many more [24].

\section{Intellectual Freedom and Means of Muslim}

The censorship has become a common theme in the academic world and in the media press, in which the key question that has not been fully addressed is how community perceive this type of policy. Actually, a person may appear to be supporter or anti-censorship but there is a possibility that he or she do not aware of its existence [25]. Research shows that users' perceptions of Internet censorship are dynamic and can be changed with the longer experienced users are more aware of online censorship than new users [26]. They also found that today's users see Internet censorship more naturally than when they discovered online censorship, which showed that most of them were accomodated extremely well with mostly every government policies. It can be explained that educational attainment, autocratic personality and monthly income are a source of mentality for not constantly looking for problems or questioning violent policies. Debert and Rosinski [27] divided the technical control mechanism into three generations, which focused on automatic screening and supervision, then used unofficial requests from the authorities to manually delete the information and eventually used statesponsored media campaigns to address the online discourse where China is at the forefront of all these techniques. In fact, the government can employ hundreds of people as commentators who act as ordinary users but in fact are pro-government publishers who comment on social media to support certain policy [28].

The term intellectual freedom is defined as a human right to consume, receive and disseminate all types of knowledge, science and information. People have the right to convey and express their ideas from any side and insight unless they pass the rights of others or harm the public in general. In a democratic country, intellectual freedom is important and very important as the basis of a system of government and in fact Islam has established principles that define idealism which are guidelines in life to ensure which are categorized as good and bad. Among these valuable principles, actually intellectual freedom has its limits that refer to the Qur'an and Sunnah as standards. Many people who live in this world really expect a free and unrestricted life with various rules. This can foster the principle of the truth of relativeness that demands absolute recognition of something that is basically unacceptable to religious teachings even by customs so as to produce an effect of moral decline and underestimate religious teachings. Despite the fact, unlimited freedom is impossible to realize in this world because the actions carried out by humans are often influenced by the impulses of lust, so that when someone leaves the norms of religion automatically he will fall prey to the rules of lust controlled by Satan and this is a source of disaster biggest for him. Indeed human lust will always lead to evil and damage, as the word of Allah Ta'ala in Surah Yusuf 12:53 and Surah Mu'minun 23:71 [1].

The broad concept of Internet censorship consists of three main mechanisms, which are government policies, social standards and technical control mechanisms [29]. At the policy 
level, the government often builds media policies and legislative frameworks to control and monitor the information spread on the Internet. At the same time, social norms can also act as a control mechanism because the social pressure of not seeing prohibited information can be an effective form of prevention. On the other hand, technical control mechanisms on the Internet, such as IP blocking, content sensing and keyword filtering, are ways to limit a user's ability to access, publish and share information online. Meanwhile, MacKinnon [30] described the network authoritarianism as the new form of tyranny, which shows China and some former Soviet republics controls many state-of-the-art talks or wide range of conversations in traditional media and new media on the Internet. Normally, the governments often follow a discourse and sometimes respond to citizens' demands for justice. As a result, citizens may feel that they have the ability to access every information in order to express themselves freely. In actual, the government often use traditional media or other channel to spread the need to control the Internet in certain levels and aspects. He believes that previous research claiming that the leaders of autocratic countries are digging their graves by providing people with the Internet has blinded many Western policymakers, activists and journalists from what has already happened in these countries and is therefore worth further exploration.

Basically, censorship policy has several reasons to be executed like helping to avoid the huge scale of conflict in the community, providing the security and safety measures to anticipate the act of terror, maintaining political stability and traditional social values, blocking the impact of cybercrime and porn addiction, stopping the false advertisements from illegal product, preventing the plagiarism in the intellectual property and controlling the panic and fear as the economic or natural disasters occur. Oppositely, censorship can be used to promote negative agenda of manipulation by restricting the information about certain things, violating the rights of citizens in term of opinion or sentiment and inhibiting potential innovation in research, development or design. However, it is impossible to completely abandon Internet management or infrastructure regulation because the Internet is a kind of mirror reflecting the real world, which there are rules in the real world, including legal rules, designed to guarantee freedom of expression and access to information, while protecting against abuse of these rights and illegal behavior [27-35]. Many Arab countries in the Middle East and North Africa are guided simultaneously by the following reasons, such as Saudi Arabia, Syria, Iran, Yemen, Bahrain, Kuwait, Tunisia, United Arab Emirates, Jordan, Tunisia, Morocco, Egypt, Ethiopia and Libya.

In some cases, sites that are religious in nature can be considered a potential threat and are therefore blocked. However, the main reason for controlling virtual space is the protection of social norms and morals, especially in relation to fighting child pornography and preventing incitement to racial hatred. In addition, web resources can be censored for security reasons, such as sites that are linked to terrorists and other extremist groups. In practice, Arab regimes have been criticized for the fact that, under the pretext of protecting the moral foundation of society, the political rights of citizens have been enforced. In this case, the preservation of traditional social values has become the facade of the real intentions of the Arab dictatorship: the suppression of political pluralism and self-expression on the Internet [30]. The role of censorship is very important to protect citizens from challenging intellectual opinions with different views even though not all of these concepts need to be applied. The analogy is that there is no need for someone to try to jump from the fourth floor, five or six of a tall building to find out that with this he will suffer a severe injury and even die [31]. Even so, cases of censorship in the community often also occur due to financial or political reasons which of course have an impact on the resistance or distrust of the people, where a policy should be discussed in depth and ask for input from the community before it is decided to become a statutory regulation. 
At present, some Governments are rearranging their regulations because of rapid changes in technological developments especially the effects of the Internet. Indeed, the government regulations should not be depended on supervisors' estimates or watchdog guesses but on the performance and quality. In some countries, such as Russia, China and Iran, they have established technology rules by creating a brand for state media through contracting critical news in each redaction. Others countries build the same regulation are Turkey, Hungary, Ecuador and Kenya by making a different tools for regulated journalist and media in their country. In fact, certain countries also applied specific regulation for internet and media censorship such as United States, Russia, Turkey, Venezuela, Pakistan, Hungary etc [32]. As a result, the internet's promise of open access to independent and diverse sources of information is a reality mostly for the minority of humanity living in mature democracies. In United States, the freedom to speak and deliver argument is protected by the First Amendment to the United States Constitution. Any kind of communication and issues of speech freedom has been stated in this rules, also about the censorship. There was a certain organization to look after all about censorship and its matters [33]. Actually, constitution is a landmark in the defense of free speech against government interference and suppression where naturally government set strategies to restrict free speech on issues, which they set each regulation for each industry. On the other hand, the refinement of internet and social media law in Turkey gave authority to Telecommunications Directorate to shut down any content or website in order to preventing the crime and shielding security in the country. They also set a law for people who huge fines in retaliation for critical coverage, applying certain regulation for tax. This mechanism is the way of Turkey to carry out censorship in country. Therefore, the corruption also become a sizable problem in this country, which they want to overcome everything about the corruption in the wider scale especially within internet matters and social media, the Telecommunications Directorate can blocked any account or website due to prevent the corruption through several social medias, also Twitter.

President of Russia has renew the law about media and journalist where the government has a particular media operation to conquer media and internet issues [34]. They also have authorization to block some Medias and website and certain limitation for foreign investment regulation in Russia through foreign media ownership, which the censorship provision was carry out by the law. In Venezuela, they combine several factor in implementing law for censorship by adopting from above country methods of censorship. At other side of the world, Pakistan have ever banned then blocked a popular TV channel in the country, which called as selfcensorship. A well-known journalist also punish by this law and receive a suspension. This means in Pakistan, self-censorship by the government is strictly applied. The use of internet rapidly grow in the world with more and more government has set certain rules for censorship. A new more adequate mechanism still needed for completing the regulation with many methods used by the state are still beneath and have appear in other countries. The combination of censorship law with others mechanism can be a better regulation to applied in a country, for example combined and comply with Islamic rules, not only imitate one country but contextually and considering good and bad consequences of the implementation [35].

\section{The State of Exception}

The rapid flow of information is the effect of technology changes, which technologies have been developed in the way of more complex than before. To deal with this situation, the 
regulator and the agency who manage and control this matter should find several challenges, which some people argued that the birth of the internet should be followed with the death of censorship. Indeed, every human deeds ora actions can be categorized into two spheres of worship (ibadah) and interaction (muamalah). The rule held in executing a practice is the law of establishing the conditions in muamalah to communicate with fellow human beings is permissible unless there is a prohibition while the origin of the legitimate condition of ibadah to perform a ritual to Allah ta'ala is not there unless there is a proposition [36]. This two conditions of rule based on Surah Baqarah 2:29 and Surah as-Syura 42:21, Shahih Bukhari, Book of Peacemaking, hadith no. 2697 and Book of Conditions, hadith no. 2721, Shahih Muslim, Book of Emancipating Slaves, hadith no. 1504, and Sunan Abi Dawud, Book of the Office of the Judge, hadith no 3594 [1-2].

\subsection{The Islamic Sources of Sacred Law}

Divine texts should be explored as the alternative interpretation to develop their full potential to reinforce the Quran's inclusive nature which promote equality and freedom of choice as intellectual that include emotional and spiritual to bring contribution to the society as whole become popular perspective refering the Islamic sources [19]. This view should be challenged as Allah ta'ala mentioned numerous times of high praises to the companions of Prophet like in Surah At Taubah 9:100, Surah Al-Hujurat 49:7 or Surah Al-Hasyr 59:9 [1]. On the other hand, Rasulullah shalallahu alaihi wasalam also mentioned in Shahih Bukhari 6065 and Shahih Muslim 2533 that the best people are those of his generation, then those who come after them, then those who come after them [2] so it can be declared in general that the understanding and practice of Islam intrisically and explicitly in the side of companions of Prophet. Of course opinions need to be adjusted as the basis of the arguments within the Qur'an and Sunnah without interpreting too broadly and widely unless a problem is not explicitly available and mentioned such as cigarette, social media, playing games, etc. Actually based on Jami at Tirmidhi, Chapter on Tafsir, hadith no. 2952, whoever said the Qur'an was limited to his opinion, then he happened to be right, so he was still wrong [2] although there is a dispute about the degree of this hadith lightly but its meaning is true. Furthermore, in Surah Al Ahzab 33:36 [1] explained that it is not right for the believers men and women to choose other options in their affairs, when Allah and His Messenger have decided upon a decree.

\subsection{Ijtihad as the Law of Inductive Logic}

Undoubtedly the absolute ijtihad has ceased since a very long time since no one fulfilled the criteria. But the door of ijtihad has not been closed even open. But where are the people who deserve it? In particular, ijtihad is not an easy matter because of its terms, components and specialties and must have established capability so that with all these things one can afford to derive the syar'i laws. Therefore, whoever does not have all these things then he may be able to notify the previous ulema and take the result of their ijtihad which is judged more strongly based on the argument in Nahl chapter 16:43 to ask a knowledgeable person with respect to a matter [1]. Sometimes it is obligatory to be obliged if he is unable to study and does not have the capability to study. Hence, it may take from the words of a trusted scholar that he would take advantage of them and walk on their light [37]. There are certain requirement should be fulfilled before conducting ijtihad for certain eligible person like deep understanding in term of legality aspect from Al Quran, the degree of autheticity from Sunnah and the agreement among scholar in the first era (Ijma'), nasikh wa mansukh (the elimination of a matter), substances of the proposition, which cause differences, dalalah lafadzh (word instructions characters) and istinbat (the ability draw conclusion) [38]. In practice, when there is a vague thing at the time, there is 
dispute where some scholars give permission to do certain act but not the least forbid those things, it is better for someone to avoid it in accordance with messenger's advice in the Shahih Bukhari, Book of Sales and Trade, hadith no. 2051 and Shahih Muslim, Book of Musaqah, hadith no. 1599 [2].

\subsection{The Deliberation of Ethics}

The recent mass shootings in two New Zealand mosques, the hate crimes that are designed to maximize exposure to social media, have created a number of ethical mysteries for news producers and consumers around the world. New Zealand has banned ownership or distribution of long stretches loaded by the 28-year-old gunman who opened fire on two mosques in Christchurch on March 15, killing nearly 50 people. Having a document on someone's computer or having a hard copy in violation can be sentenced to 10 years' imprisonment, while sending it to a person on the Internet can be punished for 14 years. This can be seen as a preventive attempt by the government to prevent the widespread spread of extreme deception that could damage the wider seeds of terrorists later on. In addition, self-censorship has become commonplace for the media in other parts of the world by not showing sadistic images clearly without conflict, such as the circumstances of murder victims, accident victims, victims of rape, blood spilled, etc. in the media. In principle, Islam invites to maintain $a d a b$ and $a k h l a q$ in terms of ethics and morals especially when preaching to somebody who do not believe in Islam yet. It is the most important part of Islamic religion to conducted by prioritizing self-intentions to Allah, the correctness of the messages, the advice has been brought and consideration of the good and bad consequences. Therefore, it is unfortunate when many media still display images or videos that reveal genitals, disgusting or sadistic things in order to increase ratings and promotions. In fact, the rights mentioned by modern international organizations are characterized by deficiencies in concepts and shortcomings in the formulation as well as the application of injustices, which are subjected to political agendas, economic pressures and culturally biased views influenced by the residues of colonialism and imperialism [39]. Interestingly, if somebody have tendency to follow most of people on earth, they will follow nothing but conjecture and lie then lead away from the way of Allah based on Surah Al-An'am 6:116 [1]. At practice, every Muslim should maintain good deeds in the daily life, which one of them is related to leave things that are not useful or does not concern him/her, based on Jami' at-Tirmidhi, Chapters on Zuhd, hadith no, 2317 [2].

\subsection{The Consequences of Media Censorship}

Interestingly, the study found four main results as the impact of media censorship, which are (1) free access alone does not encourage subjects to obtain politically sensitive information; (2) temporary encouragement leads to a continuous increase in acquisitions which demand is not always low; (3) acquisitions lead to significant, substantial changes in knowledge, beliefs, attitudes and behaviors; and (4) social transfer of information is statistically significant but small [40]. Another study found that when publicity, propaganda and censorship were low, support for the government changed in the same way in all federal regions. Therefore, after campaign, government support has increased slightly but not in high-internet penetration areas. However, the difference is short-lived within the absence of treatment to more distortion, the population of citizens will be prefer to revert to their original opinions after 2-3 weeks. On the other hand, the popularity of government-controlled television channels declined when they had high levels of propaganda, justifying the idea that slanted change was not demand driven. The number of viewers is also low as it disappears after one week so when propaganda rises, people turn off the TV but they turn it on again when the tilt level becomes more moderate [41]. Due to the 
strict censorship policy, most independent press suffer regularly from the editorial board which commonly, the panel rejected between 30 to 40 percent of the weekly stories, nearly almost half of the stories being sent useless. It became the financial losses to the newspapers and demotivate the journalist as it could not be published. In addition, this makes reporters unwilling to work hard and produce better stories that tell the real political and economic situation of the country whereas the media must appear as agents of stability, restraint and change [42],[43]. Traditional wisdom assumes that increased censorship will severely restrict access to information, although the opposite is true. Increasing censorship increases access to information for most of the population through incentives to learn ways to avoid censorship that will provide access to that information [44].

\section{Conclusion}

This paper proposed to discuss the Islamic perspective to evaluate the censorship policy imbued by the government to restrict citizen activities. It is found that examining censorship regulation become necessary to produce more qualified censorship mechanism. There several laws which organizing everything in Islam related to norms and the provisions of intellectual freedom and things about censorship. Accordingly, Al-Quran and Sunnah can be a reference in creating an ethical code and censorship norm in a country. Islamic ethics must stimulate new developments in science and technology in connection with Islamic ethics. Religion becomes a critical condition for the formulation of other forms of social control. Therefore, the intellectual freedom have to be straighten with the provision of not expressing negative matters, injuring matters, violating applicable norms and culture. Intellectual freedom in a country must be straighten and be approved, which the equality should be presented in term of treatment. It should not go beyond that such as claiming that physical and emotional differences are similar to justify the equality of right and obligation. The effort to comply with these, government could be able to manage a clear ethical codes based on Islamic rules. 


\section{References}

[1] Al Quran. : The Noble Qur'an. Accessed at June (2019) from: https://quran.com/

[2] sunnah.com.: The Hadith of the Prophet Muhammad at Your Fingertips. Accessed at June (2019) from: https://sunnah.com/

[3] Freedom House.: Indonesia Partly Free. Accessed at June (2019) from: https://freedomhouse.org/report/freedom-world/2019/indonesia

[4] SAFENET.: Peningkatan Pelanggaran Hak-hak Digital Jurnalis dan media di Indonesia. Accessed at June (2019) from: http://id.safenetvoice.org/2019/01/peningkatan-pelanggaran-hak-hak-digitaljurnalis-dan-media-di-indonesia/

[5] EIU.: White Papers. Accessed at June (2019) from: https://www.eiu.com/Handlers/WhitepaperHandler.ashx?fi=Democracy_Index_2018.pdf\&mode=wp\&ca mpaignid=Democracy 2018

[6] PFI.: President's Broken Promises. Accessed at June (2019). https://rsf.org/en/indonesia

[7] Al-Bar, M.A.: The Origins of Islamic Morality and Ethics. Contemporary Bioethics pp. 49-74 (2015).

[8] Ebrahimi, M. and Yasin, Z.: Islamic Identity, Ethical Principles and Human Values. European Journal of Multidisciplinary Studies, 6 (1), pp. 325-336 (2017).

[9] Unus, I. And Caldwell, C.: Ethical Principles of the Islamic Faith - Insight for the Modern World. Business and Management Research, 7 (3), pp. 27-35 (2018).

[10] Chowdhury, M.: Emphasizing Morals, Values, Ethics and Character Education in Science Education and Science Teaching. The Malaysian Online J. of Educational Science, 4 (2) (2016).

[11] Newell, AK.: Accountability in the Khilafah. Accessed at June (2019) from: https://www.cia.gov/library/abbottabad-

compound/8E/8E321994A7963682B49B8466F5516B1E_Accountability_in the_Khilafah.pdf

[12] Taufiq, I.: Transparency and Accountability in the Qur'an and Its Role in Building Good Governance. Int. J. of Business, Economics and Law, 6 (4), pp.73-81 (2015).

[13] Al-Aidaros, H., Shamsudin, F.M. and Idris, K.M.: Ethics and Ethical Theories from an Islamic Perspective. International Journal of Islamic Thought, 4 (2013).

[14] Faruqi, Y.M.: Islamic View of Nature and Values: Could these be answer to buidling bridges between modern science and Islamic science. Int. Education Journal, 8 (2), pp. 461-469 (2007).

[15] Rather, N.Q.: Islamic Socio-Ethics for a Just Society: An Overview. Online Int. Interdisciplinary Research Journal, VI(V), pp. 242-246 (2016).

[16] Dalhat, Y.: Islam and the Problem of Social Integration in the West. Int. Journal of Education and Research, 3 (7), pp. 273-282 (2015).

[17] Latt, S.S. and Shah, M.A.: Internet Usage from Islamic Perspective: A Preliminary Survey with First Year Medical Students, Kuantan Campu, Pahang 2015. Int. J. On Recent and Innovation Trends in Computing and Comm., 5(2), pp. 207-213 (2017).

[18] Muhdina, D.: Gender Equality Perspective in Islam based on the Holy Quran. The Social Sciences 12 (12), pp. 2314-2320 (2017).

[19] Hendricks, M.: Islamic Texts: A Source for Acceptance of Queer Individuals into Mainstream Muslim Society. The Equal Rights Review, vol. Five (2010).

[20] Bonino, S.: A New Muslim Community: Children of Islam and Scotland. Religions, 10 (175) (2019).

[21] Bolognani, M.: The Myth of Return: Dismissal, Survival or Revival? A Bradford Example of Transnationalism as a Political Instrument. Journal of Ethnic and Migration Studies 33, pp. 59-76 (2007).

[22] Green, Abdur-Raheem.: Authenticity of the Quran. Islamic Knowledge Bank. Hezb-e-Islami Afghanistan (1994). Online at http://www.hezb-e-islami.org/quran.html

[23] Hossain, M.Z.: Why is interest prohibited in Islam? A Statistical Justification. Humanomics 25, pp. 241-253 (2009).

[24] Issa, I.: Fragmentation, Censorship and an Islamic Journal: A History of the Translation of Milton into Arabic. Milton Quaterly, 46 (4), pp. 219-232 (2012).

[25] Knox, E.J.M.: Opposing Censorship in Difficult Times. Library Quaterly: Information, Community, Policy, 87 (3), pp. 268-276 (2017). 
[26] Wang, D. and Mark, G.: Internet Censorship in China. ACM Transactions on Computer-Human Interaction 22 (6): pp. 1-22 (2015).

[27] Deibert, R. and Rohozinski, R.: Liberation vs. Control: The Future of Cyberspace. Journal of Democracy, 21 (4), pp. 43-57 (2010).

[28] Sullivan, J.: China's Weibo: Is Faster Different? New Media Soc. 16 (1), pp. 24-37 (2014).

[29] Roberts, H., Zuckerman, E., and Palfrey, J.: 2007 Circumvention Landscape Report: Methods, Uses and Tools. The Berkman Center for Internet \& Society, Harvard (2009).

[30] Shishkina, A. and Issaev, L.: Internet Censorship in Arab Countries: Religious and Moral Aspects. Religions, 9 (358) (2018).

[31] Tanash, R.S., Chen, Z., Wallach, D. and Marschall, M.: The Decline of Social Media Censorship and the Rise of Self-Censorship after the 2016 Failed Turkish Coup. FOCI: USENIX Security Symposium (2017).

[32] Aryan, S., Aryan, H. and Halderman, J.A.: Internet Censorship in Iran: A First Look. FOCI: USENIX Security Symposium (2013).

[33] Nabi, Z.: The Anatomy of Web Censorship in Pakistan. arXiv preprint arXiv:1307.1144 (2013).

[34] Xu, X., Mao, Z. and Halderman, J.A.: Internet Censorship in China: where does filtering occur? Int. Conf. on Passive and active measurement, Springer-Verlag, pp. 133-142 (2011).

[35] Chaabane, A., Chen, T., Cunche, M., de Cristofaro, E., Friedman, A. and Kaafar, M.A.: Censorship in the Wild: Analyzing Internet Filtering in Syria. Internet Measurement Conference, pp. 285-298 (2014).

[36] As-Sunnah.: Hukum Asal Mu'amalah adalah Halal kecuali ada Dalil yang Melarangnya. Majalah As-Sunnah edisi 10\&11/ XVI/1433H (2012).

[37] Shalih bin Fauzan.: Apakah Pintu Ijtihad Tertutup? Andi Ihsan (trans.) Accessed at July 2019 from: https://muslim.or.id/26820-apakah-pintu-ijtihad-sudah-tertutup.html (2015).

[38] Robani, A.: Antara Ijtihad dan Taklid. Access at July 2019 from: https://almanhaj.or.id/3106antara-ijtihad-dan-taklid.html (2011).

[39] Al-Sheha, A.R.: Human Rights in Islam and Common Misconceptions. Islamabad: Islam Books (1988).

[40] Chen, Y. and Yang, D.Y.: The Impact of Media Censorship: 1984 or Brave New World? American Economic Review, 109 (6), pp. 2294-2332, June (2019).

[41] Melnikov, N.: Censorship, Propaganda and Political Popularity: Evidence from Rusia. SSRN Electronic Journal (2018).

[42] Thu, K.: The Impact of Censorship on the Development of the Private Press Industry in Myanmar/Burma. Reuters Institute Fellowship Paper (2012).

[43] Hobbs, W. and Roberts, M.E.: How Sudden Censorship can Increase Access to Information. American Political Sciencce Review, 112 (3), pp. 621-636, August (2018).

[44] Brooten, L.: Burmese Media in Transition. Int. J. of Communication 10, pp. 182-199 (2016). 